\title{
Retirement funding adequacy: The influence of provisions, attitudes and intentions
}

\begin{tabular}{|c|c|}
\hline $\begin{array}{l}\text { Authors: } \\
\text { Bomikazi Zeka } \\
\text { Chantal Rootn } \\
\text { Janine Krüger }\end{array}$ & $\begin{array}{l}\operatorname{an}^{2} \text { (1) } \\
\operatorname{lic}^{1}\end{array}$ \\
\hline $\begin{array}{l}\text { Affiliations: } \\
{ }^{1} \text { Canberra Bus } \\
\text { Faculty of Bus } \\
\text { Government a } \\
\text { University of } \\
\text { Canberra, Aus }\end{array}$ & $\begin{array}{l}\text { iness School, } \\
\text { iness, } \\
\text { ind Law, } \\
\text { Zanberra, } \\
\text { tralia }\end{array}$ \\
\hline $\begin{array}{l}{ }^{2} \text { Department } \\
\text { Management, } \\
\text { Business and } \\
\text { Sciences, Nels } \\
\text { University, Por } \\
\text { South Africa }\end{array}$ & $\begin{array}{l}\text { f Business } \\
\text { Faculty of } \\
\text { Economic } \\
\text { on Mandela } \\
\text { t Elizabeth, }\end{array}$ \\
\hline $\begin{array}{l}\text { Correspondin } \\
\text { Bomikazi Zeka } \\
\text { bomikazi.zeka } \\
\text { edu.au }\end{array}$ & $\begin{array}{l}\text { g author: } \\
\text { @canberra. }\end{array}$ \\
\hline $\begin{array}{l}\text { Dates: } \\
\text { Received: } 19 \mathrm{~J} \\
\text { Accepted: } 20 \\
\text { Published: } 23\end{array}$ & $\begin{array}{l}\text { une } 2019 \\
\text { eb. } 2020 \\
\text { Apr. } 2020\end{array}$ \\
\hline $\begin{array}{l}\text { How to cite th } \\
\text { Zeka, B., Root } \\
\text { Krüger, J., } 202 \\
\text { funding adequ } \\
\text { influence of p } \\
\text { attitudes and } \\
\text { Journal of Eco } \\
\text { Financial Scier } \\
\text { a486. https:// } \\
\text { 10.4102/jef.v1 }\end{array}$ & $\begin{array}{l}\text { is article: } \\
\text { nan, C. \& } \\
\text { 0, 'Retirement } \\
\text { lacy: The } \\
\text { ovisions, } \\
\text { ntentions', } \\
\text { nomic and } \\
\text { ces 13(1), } \\
\text { doi.org/ } \\
\text { 3i1.486 }\end{array}$ \\
\hline $\begin{array}{l}\text { Copyright: } \\
\text { (C) 2020. The A } \\
\text { Licensee: AOS } \\
\text { is licensed unc } \\
\text { Creative Comr } \\
\text { Attribution Lic }\end{array}$ & $\begin{array}{l}\text { uthors. } \\
\text { IS. This work } \\
\text { ler the } \\
\text { nons } \\
\text { ense. }\end{array}$ \\
\hline Read online: & \\
\hline 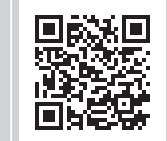 & $\begin{array}{l}\text { Scan this QR } \\
\text { code with your } \\
\text { smart phone or } \\
\text { mobile device } \\
\text { to read online. }\end{array}$ \\
\hline
\end{tabular}

Orientation: Individuals are encouraged to start saving for retirement as early as possible to ensure that sufficient retirement funding is accumulated. However, few individuals are financially independent at retirement.

Research purpose: To examine the influence of provisions, attitudes and intentions on the retirement funding adequacy of black individuals, as the majority of the South Africans are black individuals.

Motivation for the study: Despite the increased access to financial services and products, many black individuals reach retirement age destitute. This research investigated how provisions for retirement, attitudes towards retirement and retirement intentions influence the retirement funding adequacy of black South Africans.

Research approach/design and method: A quantitative approach was applied, whereby questionnaires were distributed to a sample of 441 black individuals in the Eastern Cape Province of South Africa through stratified sampling and convenience sampling.

Main findings: The results of the research revealed that retirement provisions and retirement attitudes exert the most influence on the retirement funding adequacy of black South Africans. This suggests that black South Africans should focus on amassing retirement savings and fostering a positive attitude towards retirement to ensure that they reach retirement age with adequate financial resources for retirement.

Practical/managerial implications: Financial institutions and financial planners should be aware that individuals' provisions for retirement and attitudes towards retirement are significant contributors in ensuring that retirement funding adequacy is ascertained.

Contribution/value-add: This study made a contribution in understanding the aspects that influence the retirement funding adequacy in the South African context, particularly amongst black South Africans.

Keywords: retirement attitudes; retirement funding adequacy; retirement intentions; retirement provisions; retirement savings.

\section{Introduction}

Research studies on retirement perceive it to be an important life event that includes two main features. Firstly, retirement involves an end to full-time employment or a formal departure from paid work that can be viewed as the process that begins when individuals acknowledge that their role as workers will end (Petters \& Asuquo 2008:11; Topa et al. 2011:502). Secondly, income is obtained at retirement - at least in part - from retirement savings vehicles, such as pension funds or retirement annuities (Mohidin et al. 2013:449). In the South African context, there are also other income streams that may contribute to the retirement savings of individuals; and these include government pensions, cash savings, informal savings clubs, financial support from children or extended family or income from the continuation of working past the normal retirement age (Old Mutual Retirement Monitor 2013:6). The Department of Social Development (2018) states that 3.5 million South Africans access the State Old Age Pension (SOAP) grant, and these individuals would otherwise have little or no income support for either themselves or their dependents. Individuals are also encouraged by the South African government to participate in other retirement savings vehicles to eliminate the possibility of having the SOAP grant as the only form of retirement provisions (Department of Social Development 2018). 


\section{Orientation}

The decision of how individuals should save for retirement can be difficult (Lusardi 2006:3). While those individuals who have low-income levels are constrained in their ability to save for retirement, previous research has also provided examples of medium- to high-income earners who were not making provision for their retirement (Collins et al. 2009:61; Van Der Berg 2014). A variety of reasons for not making retirement provisions include a lack of planning for one's retirement, a lack of awareness regarding retirement planning and/or a lack of interest in retirement planning (Barnes \& Taylor 2006:62). Few South Africans are able to maintain their pre-retirement level of consumption after retirement, largely because of a lack of preservation of retirement fund assets when retirement fund members leave their employment (Financial Services Board 2010; National Treasury 2014:13; Reyers 2018:345).

The responsibility of individuals in saving for their retirement includes the task of assessing their retirement investment returns, expenses in later years and increases in the cost of living (Kock \& Yoong 2011:856). Increases in life expectancies, concerns over rising healthcare costs, the state of social security and economic pressures on businesses necessitate new approaches and changes in attitude in order for individuals to understand why it is crucial for them to prepare to invest more in their own retirement (Hadley Leavell \& Maniam 2002:36).

Van Dam, Van der Vorst and Van der Heijden (2009:281) argue that individuals who have more positive attitudes towards early retirement and who feel that they have control over the early retirement decision have stronger intentions to retire early. However, previous research has shown that individuals who have negative attitudes towards retirement fear social isolation during retirement and would prefer late retirement, while individuals involved in the planning activities for their retirement are less likely to be lured into late retirement (Zappalà Depolo et al. 2008:156). Concerning retirement, it is thus possible that some individuals believe that they are not fully in the position to decide whether and when to leave their professional careers (Van Dam et al. 2009:272-273).

\section{Problem statement}

Instead of individuals becoming candidates for stateprovided welfare only, membership and participation in other retirement funds enable individuals to also benefit from these retirement funds. Failure to provide adequately for retirement may result in individuals living in poverty during the retirement years of their lives. Most South Africans reach retirement financially unprepared (Botha et al. 2014:951; Maharaj \& Reddy 2015). In particular, the black population has insufficient retirement benefits. In addition, the black population is significantly less likely than the white population to have access to private retirement funds (Barnes \& Taylor 2006:7; Butler \& Van Zyl 2012:32; Mawhinney 2010:2). In South Africa, black individuals constitute $80.2 \%$ of the population (Statistics South Africa 2014:3). Therefore, this study focuses on black South Africans residing in the Eastern Cape, as the highest levels of adult poverty are present in this province (Statistics South Africa 2020) and these individuals are more predisposed to being destitute at retirement. Thus, it is imperative to investigate how the retirement provisions, retirement attitudes and retirement intentions of black individuals in this area can influence their retirement funding adequacy.

\section{Research purpose and objectives}

The purpose of this article is to determine the factors that influence the retirement funding adequacy of black individuals in South Africa. Therefore, the primary objective is to identify and investigate the factors that influence black individuals' retirement funding adequacy. Consequently, the article provides a review of the literature on the importance of retirement funding adequacy and the factors that can possibly influence the retirement funding adequacy of individuals in South Africa. An empirical investigation is conducted amongst pre-retired individuals in the Eastern Cape in South Africa; and the study proposes recommendations to financial advisors or planners, and individuals who have not yet retired, on the ways they can improve their retirement funding adequacy, based on the factors identified in the study.

\section{Literature review}

\section{The nature and importance of retirement funding adequacy}

Retirement funding adequacy refers to the wealth or accumulated assets required at retirement to meet the retirement needs sufficiently (Butler \& Van Zyl 2012:32). Hershey, Henkens and Van Dalen (2007a:367) state that a subjective measure of savings adequacy is employed to gauge whether individuals believe that they are saving enough to retire comfortably. As is the case in South Africa, research conducted in the United States highlighted that to determine the retirement funding adequacy perceptions of individuals, information is required on the resources or the retirement savings that will be available at retirement (Bajtelsmit, Rappaport \& Foster 2013:6; Yuh, Hanna \& Montalto 1998:176). Examining individuals' perceptions of savings adequacy represents an important extension of their retirement savings such as the individuals' saving rates and retirement plan contributions (Hershey et al. 2007a:367). As such, the 'Psychological foundations of financial planning for retirement' proposed by Hershey et al. (2007b) and Ajzen's (1991) 'Theory of planned behaviour' served as a backdrop for this research, as savings decisions are influenced by behavioural and psychological attributes.

Retirement funding adequacy becomes increasingly important as having adequate income in later life enhances individuals' ability to spend during retirement as desired (Bajtelsmit et al. 2013:2). Those who have established a conscientious pattern of saving during their working years will be able to ensure 
that they have an adequate stream of retirement income (Hershey et al. 2007b:26). Another reason why it is important to examine subjective indicators of saving is because negative perceptions have been shown to lead to retirement anxiety and, ultimately, difficulties in adjusting to retirement (Lim 2003:333; Topa \& Alcover 2015:387). As a result, those who perceive their savings to be sufficient should be less likely to develop retirement anxiety and more likely to develop positive levels of retirement planning self-efficacy (Hershey et al. 2007a:367; Topa \& Alcover 2015:400).

Prior research (Barnes \& Taylor 2006:62; Financial Services Board 2012:8; Lusardi 1999:87-88) has indicated that individuals who do not plan for retirement have a poor understanding of the need for adequate retirement savings. In addition, these studies found that individuals who plan for their retirement either lack awareness of their retirement fund benefits or realise that their benefits are still inadequate in terms of providing them with the income replacement ratio they require at retirement.

\section{The factors that influence the retirement funding adequacy of individuals}

\section{Retirement provisions}

Financial resources are necessary to ensure that individuals can sustain themselves during retirement; therefore, it is imperative that individuals make provisions for retirement (Botha et al. 2014:952-953; Yuh et al. 1998:176). Retirement provisions encompass various types of financial assets that individuals anticipate they will receive from the government and employers as well as what they personally have accumulated for retirement (Bajtelsmit et al. 2013:26; Kock \& Yoong 2011:871).

Modigliani (1986) proposed that individuals save during their working lives to keep their consumption level constant once they retire. However, as previously discussed, individuals do not save enough to achieve this aim (Botha et al. 2014:951; Butler \& Van Zyl 2012:32). Although the South African retirement provisions system has shown significant commercial success, it has failed to provide adequate coverage to a significant portion of the South African population. The result has been that many individuals face significantly reduced standards of living going into retirement (Department of Social Development 2006:13; Maharaj \& Reddy 2015).

The primary concern in the retirement savings environment in South Africa is insufficient wealth accumulation by the majority of South Africans during their working lifetime, which is worsened by the lack of preservation of retirement savings (Financial Services Board 2010; National Treasury 2014:13). Thus, many South African individuals do not save their retirement provisions received from their pension or provident funds when changing jobs or employers. Those individuals who did not preserve their retirement benefits when changing employers used their savings to pay off debt, to purchase discretionary goods and/or start small businesses (Wilson 2011). Therefore, individuals who do not save or preserve their retirement provisions while changing employers are unlikely to have adequate retirement funding (Financial Services Board 2010; National Treasury 2014:13). Given the fact that few South Africans make use of retirement savings vehicles, it is evident that the retirement provisions of individuals can possibly influence the adequacy of their retirement funding. Consequently, this study hypothesises that:

$\mathbf{H}_{1}$ : There is a relationship between retirement provisions and retirement funding adequacy.

\section{Retirement attitudes}

An individual's attitude towards performing a behaviour refers to favourable or unfavourable evaluations of the perceived outcome of performing or not performing the behaviour (Segal, Borgia \& Schoenfeld 2005:46). Individuals who view retirement as a continuation of pre-retirement lifestyle tend to experience retirement as a sequence to their work role (Lai 2008:9). Individuals who have grown accustomed to thinking of themselves as competent and confident employees will carry over their positive identity to form positive attitudes towards retirement (Lai 2008:9). In addition, an individual who has lower work commitment levels and higher expectations of retirement will most likely be actively looking forward to retirement and will seek to retire as early as possible. On the other hand, individuals who possess negative expectations of retirement but who experience high levels of work commitment are most likely to wish to remain in employment and therefore wish to work beyond normal retirement age (Davies \& Cartwright 2011:253-254; Isaksson \& Johansson 2008:299; Lim 2003:333).

Expectations of retirement can vary considerably as individuals' reactions to a situation depend on their values and belief systems (Davies \& Cartwright 2011:250-251; Dulebohn \& Murray 2008:8). For some, retirement may also bring the adoption of new leisure activities as some people may expect to socialise more, travel with friends and family, or develop new interests and skills at retirement (Beehr et al. 2000:210). For others, however, retirement can be a source of real anxiety, for example, through anxiety about how one will spend one's day, anticipated decrease in social contacts, loss of structure and reduced financial security (Davies \& Cartwright 2011:251). Therefore, this study hypothesises that:

$\mathbf{H}_{2}$ : There is a relationship between retirement attitudes and retirement funding adequacy.

\section{Retirement intentions}

'Intention' refers to the willingness and extent of an individual's efforts to perform a voluntary behaviour (Ajzen 1991:181). Thus, retirement intentions can be defined as the plans an individual makes to retire completely (Zaniboni, Sarchielli \& Fraccaroli 2010:273). Psychological factors such as reduced work commitment, dissatisfaction with career attainment and anxieties about leaving the workplace positively relate to the decision to retire (Wang \& Hesketh 2012:9). Therefore, an individual who experiences low levels of job satisfaction are 
likely to leave the employ of their work and opt to retire earlier. Alternatively, an individual who experiences anxiety about leaving their workplace will rather delay retirement.

Individuals with higher levels of work commitment are most likely to retire past the retirement age when it is most financially attractive for them to leave the organisation (Davies, Van der Heijden \& Flynn 2017:2-3; Taylor \& Shore 1995:77). Therefore, work commitment can influence an individual's retirement intentions. For other individuals who have a weaker commitment to their work, their intention to retire early may occur sooner, as retirement offers older workers the opportunity to escape unsatisfying situations at work (Henkens \& Leenders 2010:309).

Burnout is a syndrome of emotional exhaustion, cynicism, a sense of ineffectiveness or a lack of accomplishment (Maslach \& Jackson 1981), resulting in reduced productivity, higher absenteeism and an intention to quit one's job (Henkens \& Leenders 2010:307). As a result, the more physically demanding a job may be, the higher the workload, the lower the challenge, the lower the growth opportunities and the degree of autonomy, the greater the likelihood of burnout occurring (Henkens \& Leenders 2010:309). Therefore, an individual who experiences burnout is likely to have the intention to retire earlier than an individual who does not experience burnout. Consequently, individuals who opt to retire early might accumulate fewer retirement savings than planned or desired (Kock \& Yoong 2011:870). For that reason, this study hypothesises that:

$\mathbf{H}_{3}$ : There is a relationship between retirement intentions and retirement funding adequacy.

\section{Research design Research approach}

The quantitative research methodology was adopted using a mixed sampling approach consisting of proportionate stratified sampling and convenience sampling. The first stratum that was applied was to ensure that the respondents are 'black individuals of African descent'. The second stratum required that respondents are between 18 and 65 years of age. Thereafter, the final stratum that was applied to the study related to retirement status (i.e. the respondents should not be retired or have ever formally retired). Once the respondents were eligible to be potential respondents, data were collected on the basis of convenience.

\section{Research method}

\section{Research participants}

A sample of 441 pre-retired black individuals in the Eastern Cape, South Africa, was the respondents.

\section{Measuring instrument}

A self-administered, self-developed measuring instrument in the form of a structured questionnaire, consisting of three sections, was used. Section A gathered the biographical and demographical data of respondents. Section B of the questionnaire gathered information relating to the retirement plans of the respondents, including their planned retirement age, membership in retirement funds and contributions into their retirement funds. Both sections A and B made use of nominal scales. Finally, section $\mathrm{C}$ of the questionnaire consisted of 23 randomised items regarding the aspects of retirement planning (Retirement provisions, Retirement attitudes and Retirement intentions) and retirement funding adequacy, based on the literature review and anecdotal evidence. This section made use of an ordinal five-point Likert-type scale ranging from 'strongly disagree' (1) to 'strongly agree' (5). The questionnaires were hand delivered to the individuals, and the completed questionnaires were hand delivered back to the researchers.

\section{Research procedure and statistical analysis}

The study calculated descriptive statistics to summarise the information about the sample (Gravetter \& Forzano 2012:396). Thereafter, exploratory factor analyses (EFAs) were conducted to determine the validity of the data collected. A rotated factor loading for a sample size of at least 100 would need to be at least 0.30 to be considered 'to meet the minimal level for interpretation of a structure' (Hair et al. 2014:115). To extract the factors from the EFA, principle axis factoring with an Oblimin (Oblique) rotation was specified as the extraction and rotation method. Oblique rotation is used when the factors are not rotated $90^{\circ}$ from each other, and the factors are considered to be correlated (Yong \& Pearce 2013:84). In addition, the Cronbach's alpha coefficients were determined to test the reliability of the measuring instrument, and it was established that Cronbach's alpha correlation coefficients $>0.6$ are an acceptable limit for reliability in an exploratory study (Hair et al. 2014:123). Pearson's product moment correlations were calculated to determine the correlations, and the strength thereof, between the variables, and the measurements are to range between -1.00 and +1.00 (Wiid \& Diggines 2013:282). Finally, a multiple regression analysis was used to test whether Retirement provisions, Retirement attitudes and Retirement intentions have an influence on Retirement funding adequacy, as the purpose of a multiple regression analysis is to investigate, simultaneously, the effects of a number of independent variables on a single dependent variable (Gravetter \& Forzano 2012:415; Zikmund et al. 2010:592). Data analysis was conducted by means of the computer software programmes Microsoft Excel and Statistica 13.

\section{Ethical considerations}

This article followed all ethical standards for a research without direct contact with human or animal subjects.

\section{Results \\ Sample description}

The majority of the respondents were female respondents $(54.65 \%)$, and the respondents mainly reside in urban 
informal areas (44.22\%). Most of the respondents were aged between 40 and 49 years (33.11\%) and indicated that their highest level of education was a national certificate or diploma (29.71\%). The majority of the respondents revealed that they were married $(49.21 \%)$ and had an employment tenure between 21 and 40 years (43.99\%).

In terms of the retirement plans of the respondents, most of the respondents have a documented retirement plan (64.63\%), whereby most of the respondents plan to retire between the ages of 61 and 65 years $(48.30 \%)$. The majority of the respondents indicated that they would like their retirement income to last between 41 and 50 years after retirement (28.12\%). The respondents provided information pertaining to their membership in pension funds and/or provident funds. Most of the respondents belong to pension funds $(56.70 \%)$ and make voluntary contributions to a retirement annuity fund $(47.17 \%)$.

\section{Validity and reliability results}

Bartlett's test of sphericity was significant $(p<0.001)$ for both the independent and dependent variables. In addition, a Kaiser-Meyer-Olkin (KMO) value of 0.823 and 0.845 was returned for the independent and dependent variables, respectively, which indicated that the data were factor analysable. Table 1 provides the validity and reliability results for respective statements used in the measuring instrument.

The results of the EFA indicated that all four items developed to measure Retirement provisions loaded together on one factor. Factor loadings of between 0.76 and 0.62 were reported for this factor, and thus, evidence of validity for this factor is provided. Retirement provisions returned a Cronbach's alpha of 0.8 , showing that the scale used to measure this factor is reliable.

The factor structure of the EFA revealed that four of the five items developed to measure Retirement attitudes loaded together on one factor. The remaining item that was intended to measure Retirement attitudes did not load on any factor and was consequently eliminated from further analyses. Factor loadings between 0.72 and 0.38 were returned for Retirement attitudes, which confirms the validity for this factor. A Cronbach's alpha of 0.66 was returned for the factor Retirement attitudes providing evidence of a reliable measuring scale for this factor.

Based on the results of the EFA, four of the five items developed to measure Retirement intentions loaded together on one factor. Only one item that was intended to measure Retirement intentions did not load on any factor and was subsequently excluded from further analyses. Factor loadings between 0.89 and 0.74 were reported for this factor, and therefore, evidence of validity is present for this factor. The Cronbach's alpha for Retirement intentions is 0.90 . Therefore, the scale measuring the factor Retirement intentions is regarded to be reliable.

All nine of the items intended to measure Retirement funding adequacy loaded together on one factor, as expected. Factor loadings between 0.75 and 0.39 are reported, and therefore, sufficient evidence of validity for the factor is

TABLE 1: Validity and reliability of retirement provisions, retirement attitudes, retirement intentions and retirement funding adequacy.

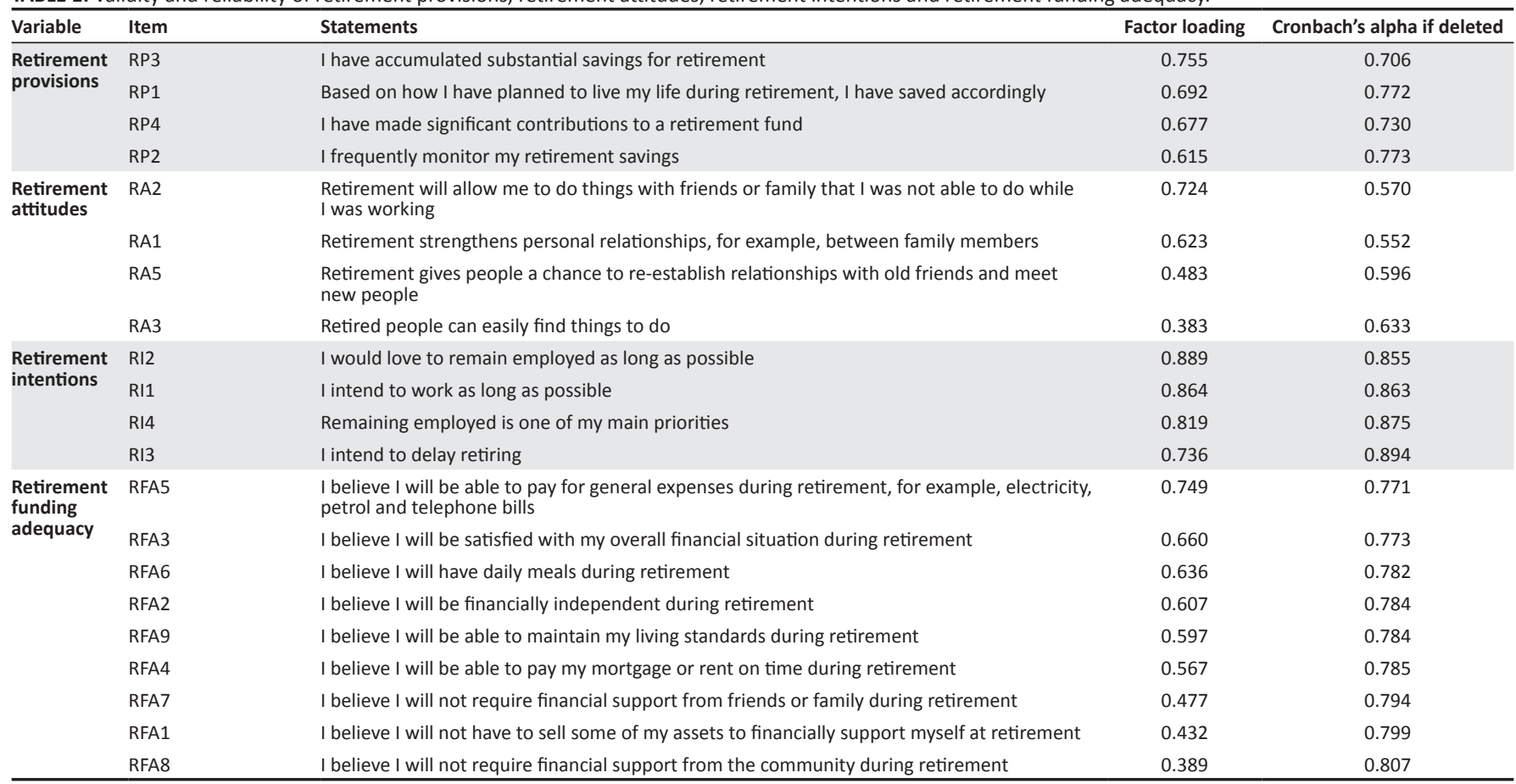

Source: Compiled from statistical results

Note: For Retirement provisions, eigenvalue:1.267; percentage of variance: 1.99; Cronbach's alpha: 0.797 . For retirement attitudes, eigenvalue: 2.885 ; percentage of variance: 1.30 ; Cronbach's alpha: 0.657 . For retirement intentions, eigenvalue: 3.945 ; percentage of variance: 2.83 ; Cronbach's alpha: 0.901 . For retirement funding adequacy, eigenvalue:3.638; percentage of variance: 3.01 ; Cronbach's alpha: 0.806

RA, retirement attitudes; RP, retirement provisions; RI, retirement intentions; RFA, retirement funding adequacy 
TABLE 2: Operational definitions, validity and reliability results.

\begin{tabular}{|c|c|c|c|}
\hline Operationalisation of factors & Items & $\begin{array}{l}\text { Factor } \\
\text { loadings }\end{array}$ & $\begin{array}{c}\text { Cronbach's } \\
\text { alpha }\end{array}$ \\
\hline $\begin{array}{l}\text { Retirement provisions refer to the } \\
\text { provisions an individual has or is } \\
\text { accumulating to contribute towards } \\
\text { his or her retirement savings. }\end{array}$ & $\begin{array}{l}\text { Developed: } 4 \\
\text { Retained: } 4\end{array}$ & $\begin{array}{l}\text { Max: } 0.755 \\
\text { Min: } 0.615\end{array}$ & 0.80 \\
\hline $\begin{array}{l}\text { Retirement attitudes refer to the } \\
\text { positive attitude of an individual } \\
\text { towards the life experience of } \\
\text { retirement. }\end{array}$ & $\begin{array}{l}\text { Developed: } 5 \\
\text { Retained: } 4\end{array}$ & $\begin{array}{l}\text { Max: } 0.724 \\
\text { Min: } 0.383\end{array}$ & 0.66 \\
\hline $\begin{array}{l}\text { Retirement intentions refer to } \\
\text { the decision by an individual to } \\
\text { remain employed as opposed to } \\
\text { retire completely. }\end{array}$ & $\begin{array}{l}\text { Developed: } 5 \\
\text { Retained: } 4\end{array}$ & $\begin{array}{l}\text { Max: } 0.889 \\
\text { Min: } 0.736\end{array}$ & 0.90 \\
\hline $\begin{array}{l}\text { Retirement funding adequacy } \\
\text { refers to the extent an individual } \\
\text { believes that he or she will be able to } \\
\text { maintain his or her standard of living } \\
\text { during retirement. }\end{array}$ & $\begin{array}{l}\text { Developed: } 9 \\
\text { Retained: } 9\end{array}$ & $\begin{array}{l}\text { Max: } 0.749 \\
\text { Min: } 0.389\end{array}$ & 0.81 \\
\hline
\end{tabular}

provided. As depicted in Table 2, the Cronbach's alpha for Retirement funding adequacy is 0.81, suggesting that the measuring scale used to measure this factor is reliable. Table 2 presents a summary of the EFA results, the Cronbach's alpha coefficients and the operational definitions of the factors.

\section{Descriptive statistics and correlations}

Retirement provisions returned a mean score of 3.743 , with the majority of the respondents agreeing (68.93\%) that they make provisions for their retirement and significant contributions into their retirement funds. Retirement attitudes reported a mean score of 3.757, implying most of the respondents agree $(71.20 \%)$ that they have positive attitudes towards retirement and associate retirement with the benefits of entering retirement. Retirement intentions returned a mean score of 3.451, with nearly twothirds of the respondents agreeing $(63.72 \%)$ that they intend to delay retirement and instead plan to remain employed for as long as possible. Finally, the dependent variable Retirement funding adequacy returned a mean score of 4.074 , whereby the majority of the respondents agreed $(84.58 \%)$ that they will be financially independent at retirement and able to maintain their standard of living at retirement.

The means of the independent and dependent variables showed that the respondents were mainly in agreement with the items measuring these four variables. Thus, respondents make provision for retirement, have positive attitudes towards retirement and intend to postpone retirement for as long as possible. In addition, respondents regard themselves to be financially independent at retirement, while maintaining their standard of living. Furthermore, responses for each of the variables were closely knitted together, as shown by the standard deviations, ranging from 0.482 for Retirement funding adequacy to 0.717 for Retirement provisions. However, Retirement intentions had the largest standard deviation of 1.096, implying that responses varied most for Retirement intentions.
TABLE 3: Descriptive statistics of the variables $(N=441)$.

\begin{tabular}{|c|c|c|c|c|c|}
\hline Factors & Mean & Standard deviation & $\begin{array}{c}\text { Disagree } \\
(\%) \dagger\end{array}$ & $\begin{array}{c}\text { Neutral } \\
(\%) \$\end{array}$ & $\begin{array}{l}\text { Agree } \\
(\%) \S\end{array}$ \\
\hline \multicolumn{6}{|l|}{ Independent variables } \\
\hline Retirement provisions & 3.743 & 0.717 & 6.80 & 24.26 & 68.93 \\
\hline Retirement attitudes & 3.757 & 0.593 & 3.40 & 25.40 & 71.20 \\
\hline Retirement intentions & 3.451 & 1.096 & 20.86 & 15.42 & 63.72 \\
\hline \multicolumn{6}{|l|}{ Dependent variable } \\
\hline $\begin{array}{l}\text { Retirement funding } \\
\text { adequacy }\end{array}$ & 4.074 & 0.482 & 0.45 & 14.97 & 84.58 \\
\hline
\end{tabular}

Source: Compiled from statistical results

$\dagger$, consists of 1-strongly disagree and 2-disagree responses.

$\$$, consists of 3-neutral or no opinion responses.

$\S$, consists of 4 -agree and 5 -strongly agree responses.

Based on the Pearson's product moment correlation coefficients, Retirement provisions presented a strong positive correlation Retirement funding adequacy ( $r=0.555 ; p=0.000)$. The variable Retirement attitudes presented moderate positive correlations with Retirement provisions $(r=0.347$; $p=0.000)$ and Retirement funding adequacy $(r=0.468 ; p=$ 0.000). The variable Retirement intentions reported a moderate positive correlation with Retirement provisions ( $r=$ $0.311 ; p=0.000$ ) and a weak positive correlation with Retirement funding adequacy $(r=0.183 ; p=0.000)$. No significant correlation was found between Retirement intentions and Retirement attitudes ( $r=-0.037 ; p=$ not significant). It is evident that the Pearson's product moment correlations show significant correlations between all the variables, except between Retirement intentions and Retirement attitudes. Furthermore, the researchers concluded that multicollinearity did not violate any of the regression results in this study, as the variables were not highly positively correlated. Table 3 summarises the descriptive statistics of the variables.

\section{Multiple regression results}

The multiple regression results show that significant positive relationships exist between two of the independent variables and the dependent variable (Retirement funding adequacy), namely Retirement provisions ( $b=0.284 ; p<0.000)$ and Retirement attitudes $(b=0.263 ; p<0.000)$. These results suggest that black individuals who have made provisions for their retirement and have a positive attitude towards retirement are likely to have adequate retirement funding. However, a positive but not significant relationship exists between Retirement intentions and Retirement funding adequacy ( $p=0.112)$. Therefore, the retirement intentions of black individuals may or may not influence the retirement funding adequacy of black individuals. The independent variables explain $40.00 \%$ of the variance in Retirement funding adequacy. The results also reveal that Retirement provisions $(t=10.045)$ exerts a greater influence on Retirement funding adequacy than Retirement attitudes $(t=8.077)$. These results suggest that individuals who have made provision for their retirement and have positive attitudes towards retirement are likely to have adequate retirement funding. Table 4 depicts the results of the multiple regression 
TABLE 4: Influence of the independent variables on retirement funding adequacy. Independent variables Dependent variable: Retirement funding

\begin{tabular}{lccc} 
& \multicolumn{3}{c}{ adequacy $\boldsymbol{R}^{\mathbf{2}}=\mathbf{0 . 4 0}$} \\
\cline { 2 - 4 } & Beta & $\boldsymbol{t}$ & Sig. $(\boldsymbol{p})$ \\
\hline Retirement provisions & 0.284 & 10.045 & $0.000^{*}$ \\
Retirement attitudes & 0.263 & 8.077 & $0.000^{*}$ \\
Retirement intentions & 0.028 & 1.593 & 0.112 \\
\hline
\end{tabular}

Source: Compiled from statistical results

$*, p<0.001$.

analysis undertaken to assess the influence of the independent variables on the dependent variable.

\section{Discussion \\ Outline of the results}

The main aspects of retirement planning influencing retirement funding adequacy are retirement provisions and retirement attitudes. Therefore, these two aspects should be the focus areas for individuals and financial advisors or planners when aiming to improve black individuals' retirement funding adequacy.

\section{Practical implications and recommendations}

Regarding retirement provisions, recruiting the assistance of a financial advisor or planner is an activity that could facilitate preparing for retirement. The findings of a study by Burke and Hung (2015:7) revealed that individuals who had consulted a pension specialist were more likely to believe that retirement planning is important and were more likely to be prepared to develop a retirement plan. Respondents in the study conducted by Burke and Hung (2015:7) in the United States reported that since working with financial advisors or planners, their financial situations have become better overall. Since developing financial plans with financial advisors or planners, this study's respondents felt more in control of their finances, were more prepared for contingencies and were more satisfied with their financial situations (Burke \& Hung 2015:7). Furthermore, making voluntary contributions into a retirement fund is a method that could improve one's retirement provisions. Voluntary savings vehicles, such as retirement annuity funds, could make a significant difference in the retirement provisions of individuals, especially for self-employed individuals or individuals who would like to make supplementary retirement savings. Individuals who have sufficient disposable income or are self-employed should explore investing in the securities market. With the guidance of a professional financial planner, a portfolio could be created that may possibly provide returns that can improve one's retirement provisions. Furthermore, individuals could potentially improve the likelihood of having adequate retirement funding if their retirement provisions include a portfolio that can generate income during retirement, such as equities that yield dividends. Individuals should also consider incorporating the SOAP fund provided by the South African government in their retirement planning, particularly those who qualify to receive the grant.
A recommendation relating to retirement attitudes is that financial advisors or planners should collaborate with counsellors to assist individuals' preparation for the transition into retirement. Through this collaboration, individuals would be able to receive an update of whether their retirement plan is still on track from a financial advisor or planner. Individuals should also continue to set personal and financial goals for themselves during retirement. Achieving goals gives individuals a sense of purpose and fulfilment. This could ultimately improve one's attitude towards retirement. Individuals who are compelled to retire by their employer could become business owners at a later stage in their lives. Although retirement denotes the departure from formal employment, not all individuals would like to remain inactive in the labour market. Therefore, starting a business could also be a venture that improves an individual's attitude towards retirement.

Therefore, it is clear that the results of this study offer relevant, practical recommendations and suggestions to individuals and financial advisors or planners on improving retirement provisions and retirement attitudes, as these two aspects can lead to improved retirement funding adequacy.

\section{Limitations of the study}

The researchers acknowledge the study's limitations. Firstly, the quantitative data presented in the study may have been subject to the self-reporting bias or social desirability bias of the respondents. Future studies may implement the prescriptions of Fisher and Tellis (1998:563-567) by using indirect questioning to reduce self-reporting bias. Secondly, this study focused on only three independent variables to determine their influence on retirement funding adequacy of individuals. Other relevant variables that could influence retirement funding adequacy, such as financial literacy, retirement literacy and demographic factors like household composition, may exist. Thus, future studies concerning retirement planning in South Africa should also investigate other factors that may have an influence on the retirement funding adequacy of black individuals in South Africa.

This study focused on black South Africans in the Eastern Cape, and as a result, the study may contain information and results that are relevant for this particular area only. Future studies could apply a qualitative approach to gain a richer understanding of the factors influencing retirement funding adequacy and endeavour to expand this study to include black individuals in other provinces within South Africa.

\section{Conclusion}

The primary objective of this study was to identify and investigate the factors that influence black individuals' retirement funding adequacy. The results of the statistical analyses performed revealed a statistically significant relationship between retirement provisions and retirement funding adequacy. Furthermore, a statistically significant 
relationship was also present between retirement attitudes and retirement funding adequacy.

The results of this study make a significant contribution to the existing body of research on the field of retirement planning in South Africa. As such, many opportunities for future investigation into the factors influencing the retirement funding adequacy of black South Africans exist, in order to ultimately improve the financial retirement readiness of these individuals.

\section{Acknowledgements Competing interests}

The authors have declared that no competing interest exists.

\section{Authors' contributions}

All authors contributed equally to this work.

\section{Funding information}

The researchers would like to thank the National Research Foundation (NRF), BANKSETA and the Nelson Mandela University for funding this study. However, these institutions played no role in the design, execution, analysis and interpretation of the data nor did they contribute in the writing up of the manuscript.

\section{Data availability statement}

Data sharing is not applicable to this article as no new data were created or analysed in this study.

\section{Disclaimer}

The views and opinions expressed in this article are those of the authors and do not necessarily reflect the official policy or position of any affiliated agency of the authors.

\section{References}

Ajzen, I., 1991, 'The theory of planned behaviour', Organizational Behaviour and Human Decision Processes 50(1), 179-211. https://doi.org/10.1016/0749-5978(91)90020-T

Bajtelsmit, V.L., Rappaport, A. \& Foster, L., 2013, Measures of retirement benefit adequacy: Which, why, for whom, and how much?, viewed 02 April 2015, from adequacy: Which, why, for whom, and how much?, view
https://benefitslink.com/links/20130115-100546.html.

Barnes, H. \& Taylor, R.F., 2006, Work, saving and retirement among ethnic minorities: A qualitative study, viewed 28 May 2014, from https://westminsterresearch. wmin.ac.uk/2915/1/Barnes,_Taylor_2006_DWP36_final.pdf.

Beehr, T.A., Glazer, S., Nielson, N.L. \& Farmer, S.J., 2000, 'Work and nonwork predictors of employees' retirement ages', Journal of Vocational-Behavior 57(2), 206-225. https://doi.org/10.1006/jvbe.1999.1736

Botha, M., Rossini, L., Geach, W., Goodall, B., Du Preez, L. \& Rabenowitz, P., 2014, The South African Financial Planning Handbook 2014, LexisNexis, Durban.

Burke, J. \& Hung, A.A., 2015, Do financial advisers influence savings behavior?, viewed 24 November 2015, from https://www.dol.gov/ebsa/pdf/conflictofinterestre searchpaper4.pdf.

Butler, M.B.J. \& Van Zyl, C.J., 2012, 'Retirement adequacy goals for South African households', South African Actuarial Journal 12(1), 31-64. https://doi.org/ 10.4314/saaj.v12i1.2

Collins, D., Morduch, J., Rutherford, S. \& Ruthven, O., 2009, Portfolios of the poor: How the world's poor live on $\$ 2$ a day, Princeton University Press, Princeton, NJ.

Davies, E. \& Cartwright, S., 2011, 'Psychological and psychosocial predictors of attitudes to working past normal retirement age', Employee Relations 33(3), 249-268. https://doi.org/10.1108/01425451111121768
Davies, E.M.M., Van der Heijden, B.I.J.M. \& Flynn, M., 2017, 'Job satisfaction, retirement attitude and intended retirement age: $A$ conditional process analysis across workers' level of household income', Frontiers in Psychology $8,1-13$. across workers' level of household incom
https://doi.org/10.3389/fpsyg.2017.00891

Department of Social Development, 2006, Reform of retirement provisions, viewed 29 March 2014, from https://www.pmg.org.za/files/gazettes/071012socdev-olderpersons.pdf.

Department of Social Development, 2018, A statistical summary of social grants in South Africa, viewed 06 December 2018, from https://www.sassa.gov.za/index. $\mathrm{php} /$ statistical-reports.

Dulebohn, J.H. \& Murray, B., 2008, Understanding risk taking in retirements savings through attitude, viewed 24 April 2014, from https://www.tiaa-crefinstitute.org/ public/pdf/institute/research/trends_issues/tr110108.pdf.

Financial Services Board, 2012, Be prepared for retirement and pension planning viewed 25 March 2014, from https://www.fsb.co.za/feedback/Documents/ Retirement\%20Funds\%20December\%202012.pdf.

Financial Services Board, 2010, A nest egg for your retirement, viewed 24 March 2014, from https://www.fsb.co.za/Departments/consumerEducation/Documents/A\%20 nest $\% 20$ egg $\% 20$ for $\% 20$ your $\% 20$ retirement.pdf

Fisher, R.J. \& Tellis, G.J., 1998, 'Removing social desirability bias with indirect questioning: Is the cure worse than the disease?', NA-Advances in Consumer Research 25, 563-567.

Gravetter, F. \& Forzano, L.B., 2012, Research methods for the behavioral sciences, 4th edn., Cengage Learning, Wadsworth, $\mathrm{OH}$.

Hadley Leavell, J.J.W. \& Maniam, B., 2002, 'Financial planning, managers, and college students', Managerial Finance 28(7), 35-42. https://doi.org/10.1108/ 03074350210767960

Hair, J.F., Black, W.C., Babin, J.B. \& Anderson, R.E., 2014, Multivariate data analysis, 7th edn., Pearson/Prentice Hall, Upper Saddle River, NJ.

Henkens, K. \& Leenders, M., 2010, 'Burnout and older workers' intentions to retire', International Journal of Manpower 31(3), 306-321. https://doi.org/10.1108/ 01437721011050594

Hershey, D.A., Henkens, K. \& Van Dalen, H.P., 2007a, 'Mapping the minds of retirement planners: A cross-cultural perspective', Journal of Cross-Cultural Psychology 38(3) 361-382. https://doi.org/10.1177/0022022107300280

Hershey, D.A., Jacobs-Lawson, J., McArdle, J. \& Hamagami, F., 2007b, 'Psychological foundations of financial planning for retirement', Journal of Adult Development 14(1), 26-36. https://doi.org/10.1007/s10804-007-9028-1

Isaksson, K. \& Johansson, G., 2008, 'Early retirement: Positive or negative for well being?', Revista de Psicología del Trabajo y de las Organizaciones 24(3), 283-301. https://doi.org/10.4321/s1576-59622008000300002

Kock, T.H. \& Yoong, F.J., 2011, 'Knowing when to retire: The first step towards financial planning in Malaysia', Educational Gerontology 37(10), 854-884. https://doi.org/ 10.1080/03601277.2010.485008

Lai, Y.J., 2008, 'Comparison and contrast of retirement attitude and personal pension purchase behavior between group aged 26 to 30 and group aged 31 to 35 in Taiwan', Master's dissertation, Nottingham University Business School, University of Nottingham, Nottingham.

Lim, V.K.G., 2003, 'An empirical study of older workers' attitudes towards the retirement experience', Employee Relations 25(4), 330-346. https://doi. org/10.1108/01425450310483361

Lusardi, A., 1999, 'Information, expectations, and savings for retirement', in H. Aaron (ed.), Behavioral dimensions of retirement economics, pp. 81-124, Brookings Institution Press and Russell Sage, Washington, DC.

Lusardi, A., 2006, Planning and financial literacy: How do women fare?, viewed 26 July 2014, from https://www.mrrc.isr.umich.edu/publications/papers/pdf/wp136.pdf.

Maharaj, V. \& Reddy, M., 2015, Dependents, debt, disinterest and withdrawal the key issues defining retirement today, viewed 16 May 2016, from https://www.fanews. co.za/article/retirement/1357/general/1358/dependents-debt-disinterest-andwithdrawal-the-key-issues-definingretirementtoday/17902.

Maslach, C. \& Jackson, S.E., 1981, 'The measurement of experienced burnout', Journa of Occupational Behaviour 2(2), 99-113. https://doi.org/10.1002/job.4030020205

Mawhinney, P., 2010, Ready for retirement? Pensions and Bangladeshi selfemployment, viewed 16 July 2014, from https://www.runnymedetrust.org/ uploads/publications/pdfs/ReadyForRetirement-2010.pdf.

Modigliani, F., 1986, 'Life cycle, individual thrift, and the wealth of nations', The American Economic Review 1(1), 297-313.

Mohidin, R., Jamal, A.A.A., Geetha, C., Sang, L.T. \& Karim, M.R.A., 2013, 'Revisiting the relationship between attitudes and retirement planning behaviour: A study on persona financial planning', International Journal of Multidisciplinary Thought 3(2), 449-461.

National Treasury, 2014, Strengthening retirement savings, viewed 12 May 2014, from https://www.treasury.gov.za/comm_media/press/2012/2012051401.pdf.

Old Mutual Retirement Monitor, 2013, South African this is what your retirement looks like, viewed 10 September 2014, from https://www.oldmutual.co.za/ documents/retirement/RetirementMonitorSummary2013.pdf.

Petters, J.S. \& Asuquo, P.N., 2008, 'Work-role attachment and retirement intentions of public school teachers in Calabar, Nigeria', Studies on Home and Community Science 2(1), 11-17. https://doi.org/10.1080/09737189.2008.11885248

Reyers, M., 2018, 'Perceptions of retirement adequacy: Evidence from South Africa', Journal of Financial Counseling and Planning 29(2),343-356. https://doi. org/10.1891/1052-3073.29.2.343 
Segal, G., Borgia, D. \& Schoenfeld, J., 2005, 'The motivation to become an entrepreneur' International Journal of Entrepreneurial Behaviour \& Research 11(1), 42-57. https://doi.org/10.1108/13552550510580834

Statistics South Africa, 2014, Mid-year population estimates, viewed 03 December 2015, from https://www.statssa.gov.za/publications/P0302/P03022014.pdf.

Statistics South Africa, 2020, Five facts about poverty in South Africa, viewed 10 February 2020, from https://www.statssa.gov.za/?p=12075.

Taylor, M.A. \& Shore, L.M., 1995, 'Predictors of planned retirement age: An application of Beehr's model', Psychology and Aging 10(1), 76-83. https://doi.org/10. 1037/0882-7974.10.1.76

Topa, G. \& Alcover, C.M., 2015, 'Psychosocial factors in retirement intentions and adjustment: A multi-sample study', Career Development International 20(4), adjustment: A multi-sample study', Career Developm

Topa, G., Moriano, J.A., Depolo, M., Alcover, C.M. \& Moreno, A., 2011, 'Retirement and wealth relationships meta-analysis and SEM', Research on Aging 33(5), 501-528. https://doi.org/10.1177/0164027511410549

Van Dam, K., Van der Vorst, J.D. \& Van der Heijden, B.I., 2009, 'Employees' intentions to retire early: A case of planned behavior and anticipated work conditions', Journal of Career Development 35(3), 265-289. https://doi.org/10.1177/ 0894845308327274

Van Der Berg, S., 2014, Black middle class plays catch-up, viewed 26 March 2016 from https://www.bdlive.co.za/opinion/2014/01/26/black-middle-class-playscatch-up.
Wang, M. \& Hesketh, B., 2012, Achieving well-being in retirement: Recommendations from 20 years of research, viewed 27 July 2014, from https://www.shrm.org/ from 20 years of research, viewed 27 July 2014, from https://www.shrm.org/ Retirement,\%20final.pdf.

Wiid, J. \& Diggines, C., 2013, Marketing research, 2nd edn., Juta, Cape Town.

Wilson, J., 2011, South Africans not saving enough for retirement: But there is still hope for the future?, viewed 31 August 2014, from https://www.sanlam.co.za/ wps/wcm/connect/3c9b558048037e198ad39ab03d1325f5/But+there+is+still+h ope+for+the+future.pdf?MOD=AJPERES.

Yong, A.G. \& Pearce, S., 2013, 'A beginner's guide to factor analysis: Focusing on exploratory factor analysis', Tutorials in Quantitative Methods for Psychology 9(2), 79-94. https://doi.org/10.20982/tqmp.09.2.p079

Yuh, Y., Hanna, S.D. \& Montalto, C.P., 1998, 'Mean and pessimistic projections of retirement adequacy', Financial 'Services Review 7(3), 175-193. https://doi. org/10.1016/S1057-0810(99)00009-8

Zaniboni, S., Sarchielli, G. \& Fraccaroli, F., 2010, 'How are psychosocial factors related to retirement intentions?', International Journal of Manpower 31(3), 271-285. to retirement intentions?', International Journal

Zappalà, S., Depolo, M., Fraccaroli, F., Guglielmi, D. \& Sarchielli, G., 2008, 'Postponing job retirement?: Psychosocial influences on the preference for early or late retirement', Career Development International 13(2), 150-167. https://doi.org/ 10.1108/13620430810860558

Zikmund, W.G., Babin, B.J., Carr, J.C. \& Griffin, M., 2010, Business research methods, 8th edn., South-Western, Montreal. 